\title{
Correction to: VSP polarization angles determination: Wysin-1 processing case study
}

\author{
Mateusz Zaręba ${ }^{1,2}$ (D) Tomasz Danek ${ }^{1}$
}

Published online: 5 March 2019

(c) Institute of Geophysics, Polish Academy of Sciences \& Polish Academy of Sciences 2019

\section{Correction to: Acta Geophysica (2018) 66:1047-1062 https://doi.org/10.1007/s11600-018-0200-8}

In the paper, the authors used data acting on the base of public procurement ZDN/014/140/2016 and related permission. They acknowledged that these data were gathered on behalf of the Faculty of Geology, Geophysics and Environmental Protection. However, unfortunately, the details related to data ownership, involvement in survey preparation as well as data acquisition were not properly provided. This omission was not intentional. Given the importance of these information, herein authors would like to acknowledge tremendous work done by Department of Fossil Fuels, a part of Faculty of Geology, Geophysics and Environmental Protection, especially by Andrzej Pasternacki, Jacek Płoskonka, Janusz Lesiak, Tomasz Maćkowski and Michał Stefaniuk. Their and our works were done in the context of scientific project GASŁUPSEJSM, a part of Blue Gas I project no. BG1/GASŁUPSEJSM/13 financed by National Center of Research and Development (NCBiR), co-financed by Polskie Górnictwo Naftowe i Gazownictwo S.A. and Orlen Upstream. The authors hope that this supplementary information as well as original acknowledgements satisfies all parts involved in the project and allows better future collaboration.

Additionally, in the original paper second author affiliation, namely Tomasz Danek's, is wrong. It should be: The Faculty of Geology, Geophysics and Environmental Protection, AGH UST, Kraków, Poland (1).

The original article can be found online at https://doi.org/10.1007/ s11600-018-0200-8.

Tomasz Danek

tdanek@agh.edu.pl

1 The Faculty of Geology, Geophysics and Environmental Protection, AGH UST, Kraków, Poland

2 R\&D Department of Seismic Signal Processing, Geofizyka Toruń S.A., Toruń, Poland 